\title{
Fever temperatures abolish bacterial hemolysis: a microcalorimetry investigation
}

Running title: Fever adversely affects bacterial hemolysis

\author{
Mihaela Palela $^{1 *}$, Elena Diana Giol ${ }^{1 *}$, Andreia Amzuta ${ }^{1}$, Oxana G. Ologu ${ }^{1}$, Razvan C. Stan ${ }^{1,2 \#}$ \\ ${ }^{1}$ Cantacuzino Military-Medical Research and Development National Institute, Romania \\ ${ }^{2}$ Chonnam National University Medical School, South Korea \\ *Equal contribution \\ ${ }^{\#}$ Correspondence: R.C. Stan, Chonnam National University Medical School, Gwangju, South \\ Korea. E-mail: $\underline{\text { strazvan@jnu.ac.kr. }}$
}

\begin{abstract}
Hemolysis modulates susceptibility to bacterial infections and predicts poor sepsis outcome. Hemolytic bacteria induce upon infection a reversible fever response from the host that may aid in pathogen clearance. We used high-sensitivity microcalorimetry to measure the evolution of heat production by fever-inducing Escherichia coli and Staphylococcus aureus under isothermal fever conditions, and determined specific aggregation profiles at temperatures equal to or exceeding $38.5^{\circ} \mathrm{C}$. We confirmed these results through bacterial incubation at relevant temperatures revealing the presence or absence of hemolysis. We reveal an additional positive role of febrile temperatures in directly contributing to the immune response, through the abolishment of hemolysis.
\end{abstract}

Keywords: fever; bacterial infections; microcalorimetry; protein aggregation; hemolysis. 


\section{Introduction}

Fever following infections is an adaptive, acute-phase response to the presence of pathogens. Transient increase in core body temperature has been associated with improved survival in sepsis and enhanced resolution of many infections, with $1^{\circ} \mathrm{C}$ rise leading to a decrease in the odds of death by $15 \% .^{1}$ However, reversible changes in baseline temperatures do not normally pass a threshold of around $40{ }^{\circ} \mathrm{C}^{2}$ suggesting the existence of an optimal range for the febrile response. ${ }^{3}$ To this end, differential scanning calorimetry (DSC) is uniquely suited to monitor heat processes resulting from thermally stressed live pathogens. ${ }^{4}$ For antigens from fever-causing pathogens, calorimetric techniques have proved essential to detect changes in immune complex formation with their monoclonal antibodies, under physiological and pathological thermal conditions. ${ }^{5}$ In hemolytic infections, extensive hemolysis leads to release of the heme moiety and to increased rate of bacterial co-infections, as most pathogens depend on environmental iron for growth, while heme itself can suppress phagocyte functions. ${ }^{6}$ We hypothesized that bacterial growth and/or infectivity with respect to hemolysis is affected at the fever temperatures they induced. We confirmed that assumption by measuring using DSC and temperature-dependent bacterial incubation on blood agar plates, compromised hemolysis in fever-inducing pathogenic bacteria.

\section{Methods and materials}

\subsection{Sample preparation}

Stocks of Escherichia coli strain 508 and Staphylococcus aureus strain 92 were stored at $-80^{\circ} \mathrm{C}$ in $30 \%$ (v/v) sterile glycerol until use. Columbia sheep blood agar plate were seeded and incubated overnight in aerobic conditions at $37^{\circ} \mathrm{C}$. Single colonies were thereafter incubated on Luria Bertani agar plates for 24 hours incubation aerobic atmosphere at $37^{\circ} \mathrm{C}$. Cells were washed with $5 \mathrm{ml}$ 
phosphate-buffer saline (PBS, $150 \mathrm{mM}, \mathrm{pH}$ 7.4). McFarland density values were determined with a DEN-1 densitometer (Biosan, USA). For calorimetry studies, samples were diluted in PBS and used immediately thereafter. For hemolysis assays on plates, $100 \mu \mathrm{L}$ of each bacterial suspension was incubated at physiological $\left(37^{\circ} \mathrm{C}\right)$ and fever temperatures $\left(38.5^{\circ} \mathrm{C}, 39.5^{\circ} \mathrm{C}\right.$ and $\left.40.5^{\circ} \mathrm{C}\right)$, on Columbia sheep blood agar plates for 24 hours. Images of plates were analyzed using ImageJ (NIH, USA).

\subsection{Calorimetric investigations}

DSC measurements were performed with a NanoDSC (TA Instruments, USA). Solutions of live cells were kept at $4{ }^{\circ} \mathrm{C}$ and degassed for 10 minutes before loading into the sample cell $(300 \mu \mathrm{L}$ active volume). Reference cell contained PBS. Equilibration time was 5 minutes before starting the scan at $20^{\circ} \mathrm{C}$ until $50^{\circ} \mathrm{C}$, with $1^{\circ} \mathrm{C} /$ minute. For the isothermal calorimetry measurements, thermal ramping was started at $20^{\circ} \mathrm{C}$ until the $37^{\circ} \mathrm{C}$ value, followed by subsequent increases to fever temperatures $\left(38.5^{\circ} \mathrm{C}, 39.5^{\circ} \mathrm{C}\right.$ and $\left.40.5^{\circ} \mathrm{C}\right)$, with an equilibration step of 5 minutes before every consequent isotherm. Data in duplicates was analyzed with OriginPro 2020b (OriginLab, USA).

\section{Results and discussion}

Both bacterial species under investigation exhibited large exothermic peaks in the temperature range of physiological interest of $36^{\circ} \mathrm{C}$ to $41^{\circ} \mathrm{C}$ indicating aggregation (Figure 1), as previously measured in other bacteria. ${ }^{7}$ A sharp endothermic peak was observed at $38.4^{\circ} \mathrm{C}$ for the $S$. aureus 92 thermogram during aggregation, indicative of a denaturation process following protein unfolding. 


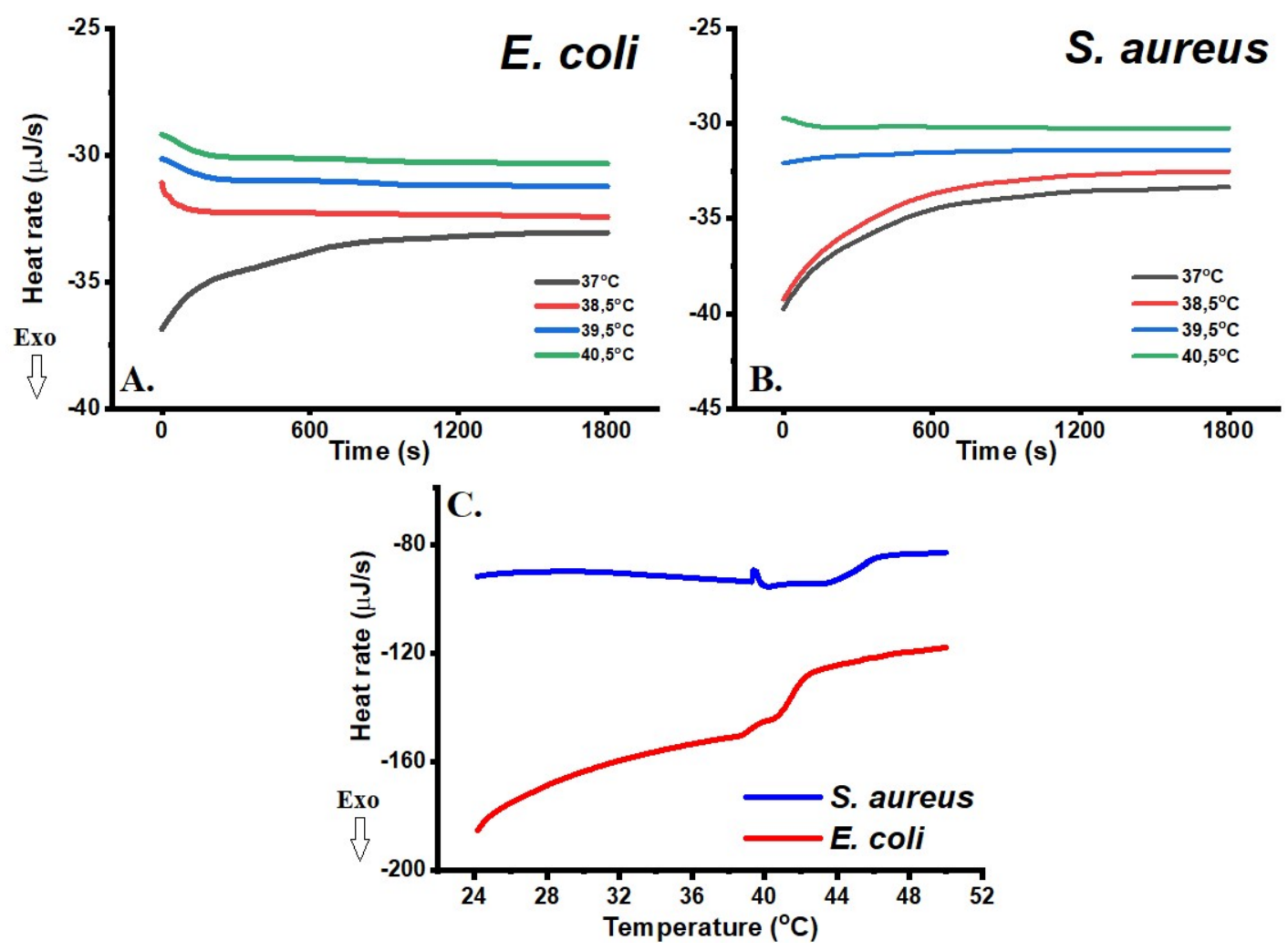

Figure 1. A, B. Averages of isothermal calorimetry thermograms at fever temperatures. C. Averages of differential scanning thermograms of live $S$. aureus and E. coli. All isothermal scans were obtained in succession starting from $37^{\circ} \mathrm{C}$, similar to the temperature changes during the fever response.

Thermodynamic parameters derived from the differential scanning thermograms indicate that the melting temperature $\left(\mathrm{T}_{\mathrm{m}}\right)$ values for both bacterial strains ranged from $38^{\circ} \mathrm{C}$ to $43^{\circ} \mathrm{C}$. For E. coli 508, two $\mathrm{T}_{\mathrm{m}}$ values were measured at $38.7^{\circ} \mathrm{C}$ and $40.6^{\circ} \mathrm{C}$; for $S$. aureus $92, \mathrm{~T}_{\mathrm{m}}$ values were present at $39.3^{\circ} \mathrm{C}$ and $43.1^{\circ} \mathrm{C}$. The presence for each species of two $\mathrm{T}_{\mathrm{m}}$ values may correspond to formation of aggregates of different oligomerization order (Figure 1 A, B). All isothermal calorimetry measurements at fever temperatures presented initial negative heat flows (Fig $1 \mathrm{C}$ ), corresponding to exothermic processes. ${ }^{8}$ We used a single exponential decay function to model the isothermal data, assuming that aggregation rate is much higher than the denaturation rate, and that a single apparent rate constant characterizes the aggregation process. ${ }^{8}$ We modeled the decrease in heat signals observed in the isotherms using the exponential decay function: 
$\mathbf{y}=\mathbf{y}_{\mathbf{0}}+\mathbf{A} \exp (-\mathbf{x} / \mathbf{T})$

where $\mathrm{y}_{0}=$ offset, $\mathrm{A}=$ amplitude, $\mathrm{T}=$ time constant parameters were varied until best fits were obtained. Adjusted R-square coefficients ranged from 0.95 to 0.97 . We derived, from the time constant parameter, the decay rate: $\mathrm{k}=1 / \mathrm{t}_{1}$ and half-life: $\tau=\mathrm{t}_{1} * \ln (2)$ parameters. Fitting parameters for all curves are summarized in Table 1.

Table 1. Fitting parameters for isothermal calorimetry data according to equation 1.

\begin{tabular}{cccccc}
\hline S. aureus 92 & Yo & A & T (sec) & Decay rate $(\boldsymbol{\mu J} / \mathbf{s e c})$ & Half-life (sec) \\
\hline $37^{\circ} \mathrm{C}$ & -33.3 & -6.1 & 371 & 0.0026 & 257.1 \\
$38.5^{\circ} \mathrm{C}$ & -32.4 & -6.6 & 363 & 0.0027 & 251.6 \\
$39.5^{\circ} \mathrm{C}$ & -31.3 & -0.7 & 402 & 0.0024 & 278.6 \\
$40.5^{\circ} \mathrm{C}$ & -30.1 & 0.6 & 43 & 0.014 & 61 \\
\hline $\boldsymbol{E}$. coli 508 & Yo & $\mathbf{A}$ & $\mathbf{T}(\mathbf{s e c})$ & Decay rate $(\boldsymbol{\mu J} / \mathbf{s e c})$ & Half-life (sec) \\
\hline $37^{\circ} \mathrm{C}$ & -33 & -3.4 & 391 & 0.003 & 271 \\
$38.5^{\circ} \mathrm{C}$ & -32 & 1 & 73 & 0.013 & 50.4 \\
$39.5^{\circ} \mathrm{C}$ & -31 & 0.95 & 241 & 0.003 & 147.6 \\
$40.5^{\circ} \mathrm{C}$ & -30.3 & 0.8 & 108 & 0.005 & 74 \\
\hline
\end{tabular}

For $S$. aureus 92 , similar decay rates obtained in the $37^{\circ} \mathrm{C}$ to $39.5^{\circ} \mathrm{C}$ range are comparatively lower by an average factor of 5 than the heat dissipation rates obtained at $40.5^{\circ} \mathrm{C}$, indicative of aggregation at this temperature. However, compared to other temperatures, higher decay rate by an average factor of 4 was observed for E. coli 508 at $38.5^{\circ} \mathrm{C}$. These values may relate to the double $\mathrm{T}_{\mathrm{m}}$ peaks observed in scanning calorimetry and reinforce the notion of aggregates of distinct oligomerization order formed at dissimilar temperatures with different thermal decay rates. Accordingly, the half-lives of the heat signals at the highest temperature are reduced by an average factor of 4 compared to the value at $37^{\circ} \mathrm{C}$ for $S$. aureus 92 , and by an average factor of 5 for $E$. coli 508, respectively, suggestive of faster aggregation processes. We note that temperatureinduced generation of kinetically trapped cytolysin species has been measured that resulted in 
either partial or full pore formation, depending on initial protein concentration and thermal stimulus used. ${ }^{9}$

Cultured plates at fever temperatures indicated absence of hemolysis at $40.5^{\circ} \mathrm{C}$ and differential absence of hemolysis at other temperatures (Figure 2 and Supplementary figure 1).
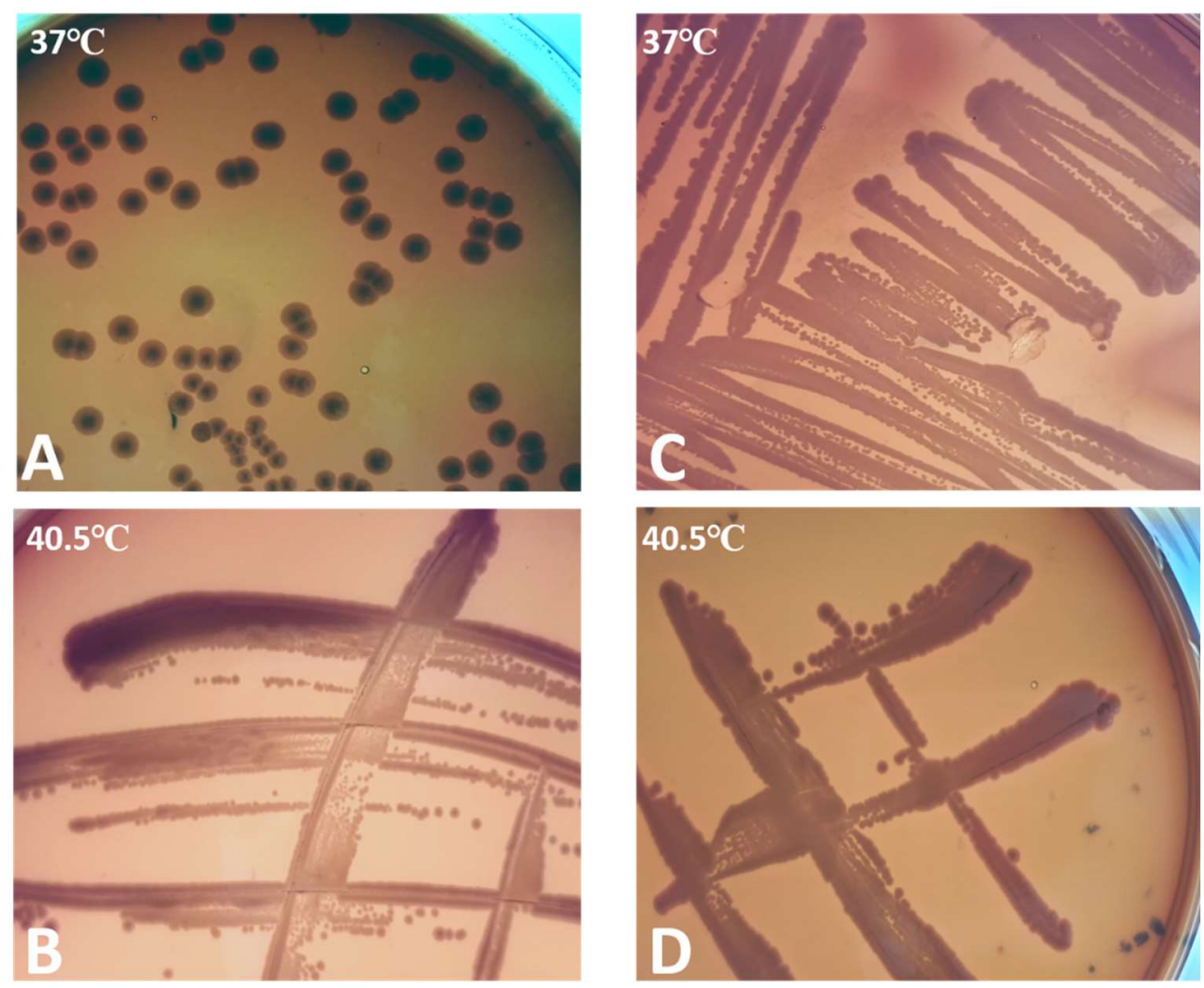

Figure 2. Alpha and gamma-hemolysis of E. coli 508 (A and B, respectively). Beta and gamma-hemolysis of S. aureus 92 (C and D, respectively). Plates were incubated for 24 hours at indicated temperatures.

Previous studies evaluating the thermal inactivation of E. coli using DSC identified key thermal endothermal peaks: at $\sim 56^{\circ} \mathrm{C}, 70^{\circ} \mathrm{C}-80^{\circ} \mathrm{C}, 94^{\circ} \mathrm{C}, 102.5^{\circ} \mathrm{C}$ and $115^{\circ} \mathrm{C}$ corresponding to denaturation of the $30 \mathrm{~S}$ ribosomal elements, of ribosomes of greater size, the fusion of the DNA, the initial denaturation of the cell wall and the full denaturation of the outer cell wall, respectively. ${ }^{10}$ We have instead focused exclusively on the thermal response of these feverinducing bacteria in a physiologically relevant range. Importantly, hemolysis of plated red blood 
cells alone, strictly achieved through temperature, is not present until a $45^{\circ} \mathrm{C}$ threshold is reached after 24 hours of incubation. At that temperature, a lipid multilayer forms that induces hemolysis in the presence of temperature stress alone. ${ }^{11}$ Bacterial hemolysis is mediated by pore-forming oligomer toxins that are important immunogens and bacterial virulence factors. While the monomers are themselves heat-stable, pore formation on the surface of red blood cell is a kinetic process that depends critically on temperature and monomer concentration. ${ }^{12}$ In E. coli, key poreforming cytolysin A slowly aggregates into two distinct oligomer species, when incubated overnight at $37^{\circ} \mathrm{C}$. These aggregates are irreversible, off-pathway products of pore complex assembly, with only about $1 \%$ hemolytic activity compared with identical mass concentrations of freshly prepared ClyA monomers. ${ }^{13}$ In $S$. aureus, oligomerization of the immunogen hemolytic agent streptolysin $\mathrm{O}$ on erythrocyte membranes is optimal in the $34^{\circ} \mathrm{C}-37^{\circ} \mathrm{C}$ range and decreases at $40^{\circ} \mathrm{C} .{ }^{14}$ Furthermore, clumping factor B from $S$. aureus that promotes, among other roles, bacterial adhesion to host tissues and hemolysis, is composed of three subdomains of which the $\mathrm{N} 3$ domain unfolds at $38.5 \pm 1.4^{\circ} \mathrm{C}$, adversely affecting activity. ${ }^{15} \mathrm{We}$ propose that the calorimetric features we measured are associated mainly with the exothermic aggregation of pore-forming bacterial toxins. Importantly, thermal stress did not impair bacterial survival, as viability assays subsequent to DSC measurements showed normal bacterial growth. We note that in conditions such as the hemolytic-uremic syndrome caused by E. coli, fever is an important initial symptom ${ }^{16}$ and moderate hyperthermia therapy $\left(38^{\circ} \mathrm{C}\right.$ to $\left.42^{\circ} \mathrm{C}\right)$ is currently used in an adjuvant setting. ${ }^{17}$

\section{Conclusions}

This study describes an in vitro role of fever temperatures on bacterial hemolysis, and the potential to monitor bacterial heat response using microcalorimetry. Because the bacterial species here investigated are fever-inducing and hemolytic in clinical conditions, further study of similar 
bacteria is warranted. Furthermore, hospital management of fever may be important as an adjuvant for treatment of relevant bacterial infectious diseases.

\section{Declaration of Competing Interest}

None.

\section{CRediT authorship contribution statement}

Mihaela Palela: Methodology, Conceptualization, Validation, Formal analysis. Elena D. Giol:

Conceptualization, Formal analysis, Visualization, Writing - review \& editing. Andreia Amzuta:

Methodology, Validation, Formal analysis. Oxana G. Ologu: Methodology, Validation, Formal analysis. Razvan C. Stan: Methodology, Conceptualization, Validation, Formal analysis, Writing - original draft, Writing - review \& editing.

\section{Funding information}

No funding was required for this study.

\section{Acknowledgments}

We thank Dr. Maristela M. de Camargo for useful comments on the manuscript. 


\section{References}

1. Schell-Chaple HM, Puntillo KA, Matthay MA, Liu KD. Body temperature and mortality in patients with acute respiratory distress syndrome. Am J Crit Care 2015; 24: 1523. DOI: $10.4037 /$ ajcc2015320.

2. Jiang Q, Cross AS, Singh IS, Chen TT, Viscardi RM, Hasday JD. Febrile core temperature is essential for optimal host defense in bacterial peritonitis. Infect Immun 2000; 68: 1265-70. DOI: $10.1128 /$ iai.68.3.1265-1270.2000.

3. Fisher DT, Vardam TD, Muhitch JB, Evans SS. Fine-tuning immune surveillance by feverrange thermal stress. Immunol Res 2010; 46: 177-88. DOI: $10.1007 / \mathrm{s} 12026-009-8122-9$.

4. Brannan AM, Whelan WA, Cole E, Booth V. Differential scanning calorimetry of whole Escherichia coli treated with the antimicrobial peptide MSI-78 indicate a multi-hit mechanism with ribosomes as a novel target. PeerJ 2015; 17: e1516. DOI:10.7717/peerj.1516.

5. Stan RC, Françoso KS, Alves RPS, Ferreira LCS, Soares IS, de Camargo MM. Febrile temperatures increase in vitro antibody affinity for malarial and dengue antigens. PLOS Negl Trop Dis 2019; 13: e0007239. DOI: https://doi.org/10.1371/journal.pntd.0007239.

6. Martins R, Maier J, Gorki A. et al. . Heme drives hemolysis-induced susceptibility to infection via disruption of phagocyte functions. Nat Immunol 2016; 17, 1361-1372. DOI: https://doi.org/10.1038/ni.3590.

7. Lepock JR. Measurement of protein stability and protein denaturation in cells using differential scanning calorimetry. Methods 2005; 35: 117-25. DOI: 10.1016/j.ymeth.2004.08.002. 8. Schön A, Clarkson BR, Jaime M, Freire E. Temperature stability of proteins: analysis of irreversible denaturation using isothermal calorimetry. Proteins 2017; 85: 2009-2016. DOI: $10.1002 /$ prot.25354.

9. Gilbert RJ, Sonnen AF. Measuring kinetic drivers of pneumolysin pore structure. Eur Biophys J. 2016; 45:365-76. DOI: 10.1007/s00249-015-1106-X.

10. Lee J, Kaletunç G. Calorimetric determination of inactivation parameters of microorganisms. $J$ Appl Microbiol 2002; 93:178-89. DOI: https://doi.org/10.1046/j.13652672.2002.01677.x.

11. Gershfeld NL, Murayama M. Thermal instability of red blood cell membrane bilayers: Temperature dependence of hemolysis. $J$ Membrain Biol 1988; 101:67-72. DOI: https://doi.org/10.1007/BF01872821.

12. Gilbert RJ, Sonnen AF. Measuring kinetic drivers of pneumolysin pore structure. Eur Biophys J 2016; 45: 365-376. DOI: 10.1007/s00249-015-1106-X.

13. Roderer D, Benke S, Schuler B, Glockshuber R. Soluble oligomers of the pore-forming toxin Cytolysin A from Escherichia coli are off-pathway products of pore assembly. $J$ Biol Chem 2016; 291: 5652-5663. DOI: 10.1074/jbc.m115.700757.

14. Palmer M, Valeva A, Kehoe M, Bhakdi S.. Kinetics of streptolysin O self-assembly. Eur J Biochem 1995; 231: 388-395. DOI: 10.1111/j.1432-1033.1995.tb20711.x.

15. Perkins S, Walsh EJ, Deivanayagam CC, Narayana SV, Foster TJ, Höök M. Structural organization of the fibrinogen-binding region of the clumping factor B MSCRAMM of Staphylococcus aureus. J Biol Chem 2001; 276: 44721-44728. DOI: 10.1074/jbc.M106741200. 16. Cody EM, Dixon BP. Hemolytic Uremic Syndrome. Pediatr Clin North Am 2019; 66: 235246. DOI: $10.1016 /$ j.pcl.2018.09.011.

17. Repasky EA, Evans SS, Dewhirst MW. Temperature matters! And why it should matter to tumor immunologists. Cancer Immunol Res 2013; 1: 210-216. DOI: 10.1158/2326-6066.CIR$\underline{13-0118 .}$ 